\title{
Cadmium background pollution in Jiaozhou Bay
}

\author{
Dongfang Yang ${ }^{1,2,3, a}$, Fengyou Wang ${ }^{1,2, b, c}$, Xiuqin Yang ${ }^{1,2}$, Ming Wang ${ }^{1,2}$ \\ and Sixi Zhu ${ }^{1,2}$
}

${ }^{1}$ Research Center for Karst Wetland Ecology, Guizhou Minzu University, Guiyang 550025, China;

${ }^{2}$ College of Chemistry and Environmental Science, Guizhou Minzu University, Guiyang 550025, China;

${ }^{3}$ North China Sea Environmental Monitoring Center, SOA, Qingdao 266033, China.

adfyang_dfyang@126.com, bcorresponding author; cfywang@163.com.cn

Keywords: Cadmium; Content; Distribution; Pollution background; Jiaozhou Bay.

\begin{abstract}
This paper analyzed the content and distribution of Cadmium (Cd) in surface waters in Jiaozhou Bay in 1984. Results showed that Cd contents in the study area ranged from 0.06-0.20 $\mu \mathrm{g}$ $\mathrm{L}^{-1}$, and were meeting Grade I $\left(1.00 \mu \mathrm{g} \mathrm{L}^{-1}\right)$ in National Sea Water Quality Standard (GB 3097-1997), indicated that this bay has not been polluted by Cd in 1984. In according to the distribution of $\mathrm{Cd}$, we found that marine current was the major pollution source of $\mathrm{Cd}$, and the source strengths were $0.17-0.20 \mu \mathrm{g} \mathrm{L} \mathrm{L}^{-1}$. However, Cd contents in the bay were $0.06-0.12 \mu \mathrm{g} \mathrm{L}^{-1}$, indicated that $\mathrm{Cd}$ pollution level in the inflow streams was very low in 1984. A content range of 0.06-0.20 $\mu \mathrm{g} \mathrm{L}^{-1}$ could be considered as pollution background of Cd in Jiaozhou Bay.
\end{abstract}

\section{Introduction}

A large amount of CD-containing waste waters were generated and discharged to rivers and marine bays along with the rapid increase of industry and agriculture [1-2]. Cd is toxic and bioaccumulative, and Cd pollution in the environment could be harmful to human being food chain. Hence, the research on the contents, pollution levels and sources of $\mathrm{Cd}$ in marine bay was essential to protect the marine environment and to maintain the harmonious development of society economy and ecological environment [3-7]. This paper analyzed the content and distribution of Cd in surface waters in Jiaozhou Bay in 1984, discussed the pollution level and source of Cd, and provided background information of $\mathrm{Cd}$ pollution for further research, as well as pollution control and environmental remediation.

\section{Material and method}

Jiaozhou Bay $\left(35^{\circ} 55^{\prime}-36^{\circ} 18^{\prime} \mathrm{N}, 120^{\circ} 04^{\prime}-120^{\circ} 23^{\prime} \mathrm{E}\right)$ is a semi-closed bay located in the south of Shandong Province, eastern China (Fig. 1). The total area and bay mouth depth $446 \mathrm{~km}^{2}$ and $3 \mathrm{~km}$, respectively. The bay has more than ten inflow rivers, including Haibo Rriver, Licun Rriver and Loushan Rriver etc., all of which have seasonal features [8-9]. The data was provided by North China Sea Environmental Monitoring Center. The survey was conducted in July, August and October 1984 (Fig. 1). Cd in surface waters in six sampling sites (namely 2031, 2032, 2033, 2034, 2035 and 2047, respectively) was sampled and monitored follow by National Specification for Marine Monitoring [10]. 


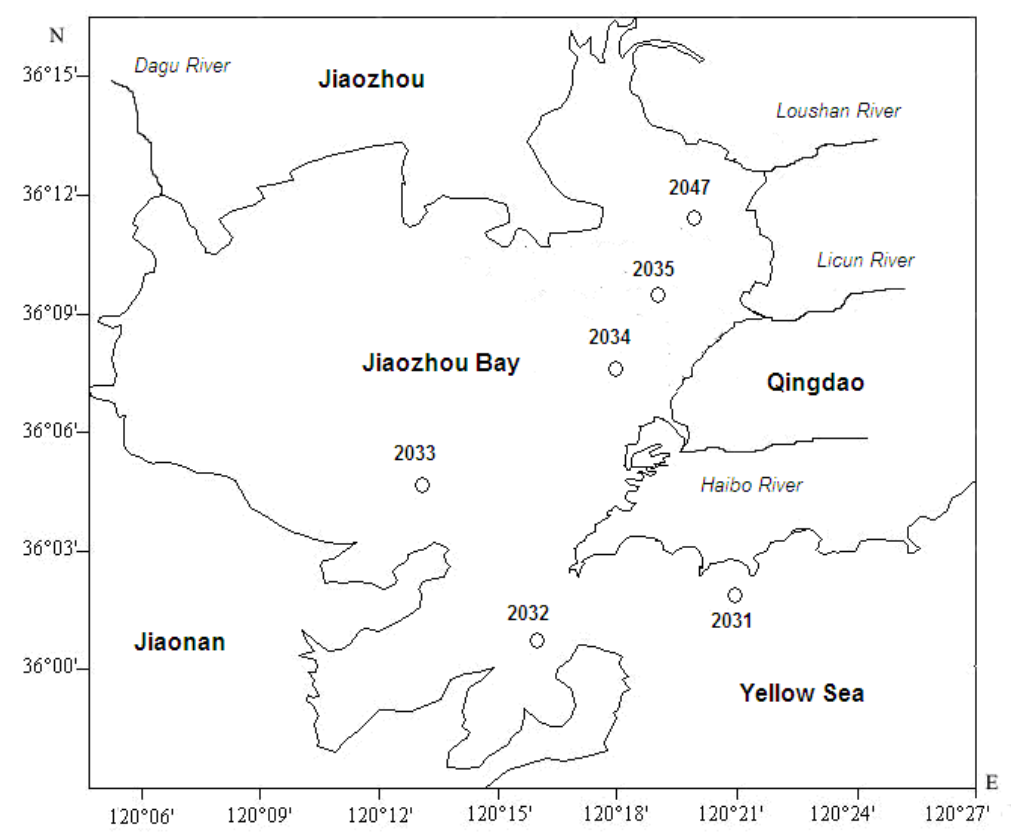

Fig.1 Investigation sites in Jiaozhou Bay

\section{Results and discussion}

Contents and pollution levels of $\mathrm{Cd}$. The contents of $\mathrm{Cd}$ in surface waters in all of the sampling sites in July, August and October were 0.06-0.17 $\mu \mathrm{g} \mathrm{L}^{-1}, 0.10-0.11 \mu \mathrm{g} \mathrm{L}^{-1}$ and $0.08-0.20$ $\mu \mathrm{g} \mathrm{L}^{-1}$, respectively (Table 1 ). In waters inside the bay, Cd in surface waters in July, August and October were 0.06-0.11 $\mu \mathrm{g} \mathrm{L}^{-1}, 0.10-0.11 \mu \mathrm{g} \mathrm{L} \mathrm{L}^{-1}$ and $0.08-0.12 \mu \mathrm{g} \mathrm{L}^{-1}$, respectively (Table 1). As a whole, Cd contents in all of the sampling sites in different seasons were lower than guide line of Grade I (1.00 $\left.\mu \mathrm{g} \mathrm{L}^{-1}\right)$ in National Sea Water Quality Standard (GB 3097-1997) for Cd.

In generally, $\mathrm{Cd}$ contents in the inside of the bay were lower than in the open waters. It was worthy pointing out that $\mathrm{Cd}$ contents in the estuaries of the major inflow rivers were lower than in the open waters, indicated Cd might be transported from marine current rather than from river flow discharge. This bay has not been polluted by Cd in 1984 and the contents range could be considered as pollution background in Jiaozhou Bay.

Table1 Pollution level of Cd in July, August and October 1984

\begin{tabular}{|c|c|c|c|}
\hline Month & July & August & October \\
\hline Inside the bay $/ \mu \mathrm{g} \mathrm{L}^{-1}$ & $0.06-0.11$ & $0.10-0.11$ & $0.08-0.12$ \\
\hline Study area $/ \mu \mathrm{g} \mathrm{L}^{-1}$ & $0.06-0.17$ & $0.10-0.11$ & $0.08-0.20$ \\
\hline Water quality grade & $\mathrm{I}$ & $\mathrm{I}$ & $\mathrm{I}$ \\
\hline
\end{tabular}

Horizontal distributions and sources of Cd. In July, there was a high value $\left(0.17 \mu \mathrm{g} \mathrm{L}^{-1}\right)$ region around Site 2031 in the open water outside the bay mouth, and there were a series of parallel lines decreasing from the open waters to the bay mouth $\left(0.16 \mu \mathrm{g} \mathrm{L}^{-1}\right)$, and to the center of the bay (0.06 $\mu \mathrm{g} \mathrm{L}^{-1}$ ) (Fig. 2). Cd contents in July were decreasing from the open water to the bay mouth and to the center of the bay, along with the flow direction of marine current, indicated that marine current was the major source, whose source strength was $0.17 \mu \mathrm{g} \mathrm{L}^{-1}$.

In August, there was a high value $\left(0.11 \mu \mathrm{g} \mathrm{L}^{-1}\right)$ region around Site 2035 in the estuary of Licun River in the northeast of the bay, and there were a series of semi- concentric circles decreasing from the estuary of Licun River to the estuary of Loushan River $\left(0.10 \mu \mathrm{g} \mathrm{L}^{-1}\right)$. Cd contents in August were homogeneous in the whole study area, and Cd contents in waters inside the bay and the bay mouth were same, indicated that the source strength of marine was $0.11 \mu \mathrm{g} \mathrm{L}^{-1}$.

In October, there was a high value $\left(0.20 \mu \mathrm{g} \mathrm{L}^{-1}\right)$ region around Site 2031 in the open waters outside the bay mouth, and there were a series of parallel lines decreasing from the open water to 
the bay mouth $\left(0.12 \mu \mathrm{g} \mathrm{L}^{-1}\right)$, and to the estuary in the northeast of the bay (0.08 $\left.\mu \mathrm{g} \mathrm{L}^{-1}\right)$ (Fig. 3). Cd contents in October were decreasing from the open water to the bay mouth and to the center of the bay, along with the flow direction of marine current, indicated that marine current was the major source, whose source strength was $0.20 \mu \mathrm{g} \mathrm{L}{ }^{-1}$.

In generally, marine was only source of Cd in Jiaozhou Bay, and the source strength was 0.17-0.20 $\mu \mathrm{g} \mathrm{L}^{-1}$, which was lower than guide line of Grade I $\left(1.00 \mu \mathrm{g} \mathrm{L}^{-1}\right)$ in National Sea Water Quality Standard (GB 3097-1997) for Cd.

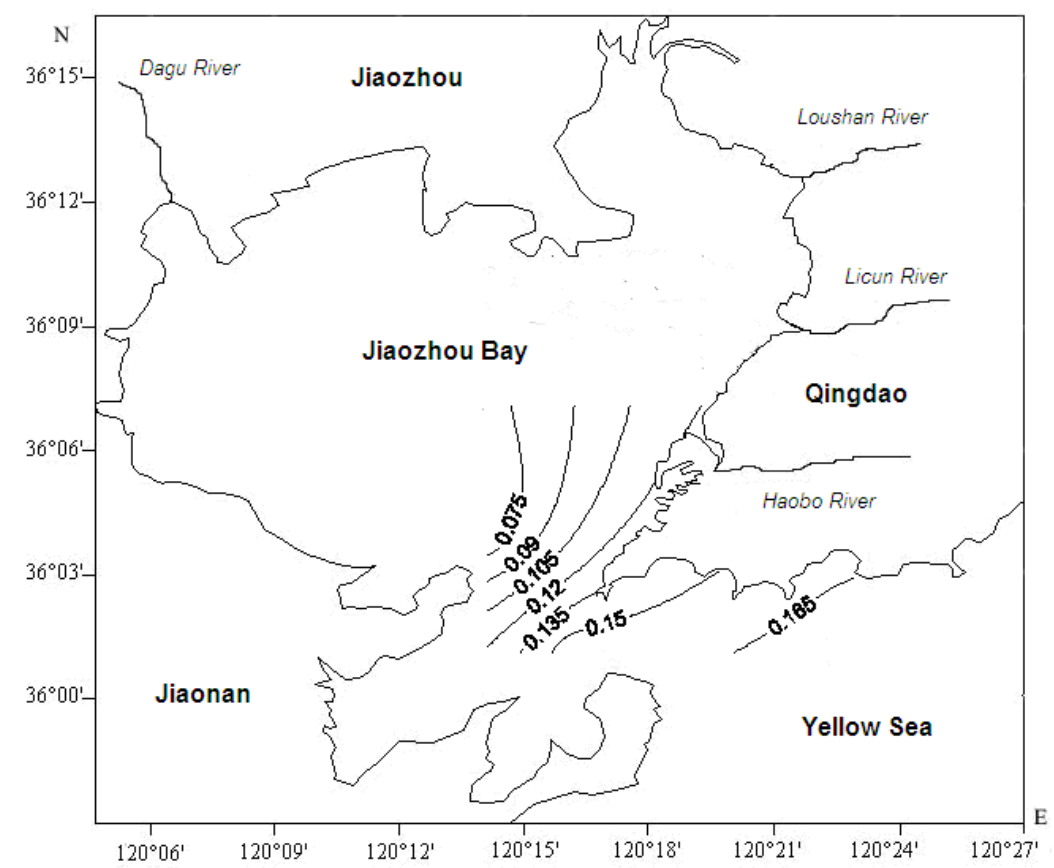

Fig. 2 Distributions of Cd in surface waters in Jiaozhou Bay in July $\left(\mu \mathrm{g} \mathrm{L} \mathrm{L}^{-1}\right)$

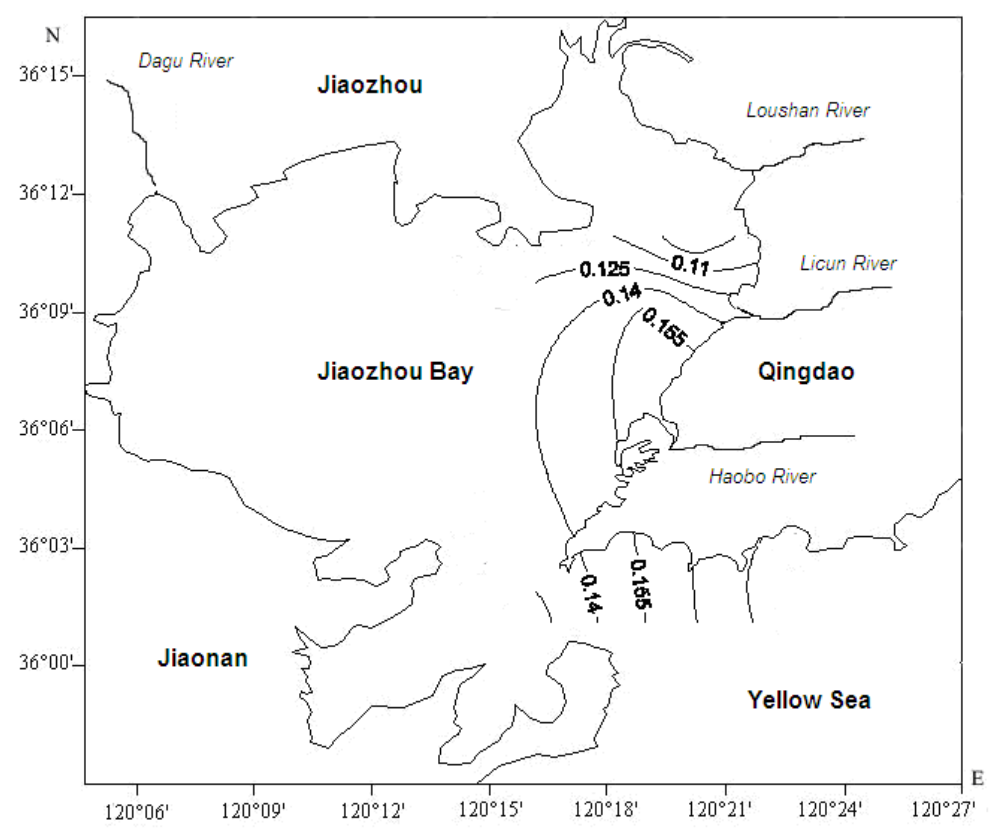

Fig. 3 Distributions of Cd in surface waters in Jiaozhou Bay in October $\left(\mu \mathrm{g} \mathrm{L}{ }^{-1}\right)$

\section{Conclusion}

The contents of Cd in surface waters in all of the sampling sites in July, August and October were 0.06-0.17 $\mu \mathrm{g} \mathrm{L}^{-1}, 0.10-0.11 \mu \mathrm{g} \mathrm{L}^{-1}$ and 0.08-0.20 $\mu \mathrm{g} \mathrm{L}^{-1}$, respectively, and were lower than guide line of Grade I (1.00 $\left.\mu \mathrm{g} \mathrm{L}^{-1}\right)$ in National Sea Water Quality Standard (GB 3097-1997) for Cd. 
Cd contents in July and October were decreasing along with the flow direction of marine current, while in August were homogeneous in the whole study area. Marine was only source of Cd in Jiaozhou Bay, and the source strength was $0.17-0.20 \mu \mathrm{g} \mathrm{L}^{-1}$, which was lower than guide line of Grade I for Cd. This bay has not been polluted by Cd in 1984 and a content range of 0.06-0.20 $\mu \mathrm{g}$

$\mathrm{L}^{-1}$ could be considered as pollution background of Cd in Jiaozhou Bay.

\section{Acknowledgement}

This research was sponsored by Doctoral Degree Construction Library of Guizhou Nationalities University, Education Ministry's New Century Excellent Talents Supporting Plan (NCET-12-0659), the China National Natural Science Foundation (31560107) and Research Projects of Guizhou Nationalities University ([2014]02), Research Projects of Guizhou Province Ministry of Education (KY [2014] 266), Research Projects of Guizhou Province Ministry of Science and Technology (LH [2014] 7376).

\section{References}

[1] Yang DF and Miao ZQ: Marine Bay Ecology (I): Beijing, Ocean Precess, (2010), p. 1-320. (in Chinese)

[2] Yang DF and Miao ZQ: Marine Bay Ecology (II): Beijing, Ocean Precess, (2010), p. 1-330. (in Chinese)

[3] Yang DF, Chen Y, Wang H, et al.: Coastal Engineering, Vol. 29 (2010), p. 73-82. (in Chinese)

[4] Yang DF, Chen Y, Chang YX, et al.: Coastal Engineering, Vol. 32 (2013), p. 68-78. (in Chinese)

[5] Yang DF, Wang FY, Wu YF, et al.: Applied Mechanics and Materials, Vol. 644-650 (2014), p. 5329-5312.

[6] Yang DF, Chen ST, Li BL, et al.:Proceedings of the 2015 international symposium on computers and informatics, (2015), p. 2667-2674.

[7] Yang D F, Chen Y, Gao Z H, Zhang J, et al.:Chin. J. Oceanol. Limnol., Vol. 23(2005): 72-90.

[8] Yang DF, Wang F, Gao ZH, et al.: Marine Science, Vol. 28 (2004), p. 71-74. (in Chinese)

[9] State Ocean Administration. The specification for marine monitoring: Beijing, Ocean Precess, (1991).

[10]Yang DF, Wang FY, He HZ, et al.: Proceedings of the 2015 international symposium on computers and informatics, (2015): 2655-2660. 